\title{
Validation of an estimated food record
}

\author{
Anne Chinnock* \\ School of Nutrition, University of Costa Rica, Apartado Postal 28-2050, San Pedro Montes de Oca, San José, \\ Costa Rica, Central America
}

Submitted 16 April 2004: Accepted 28 November 2005

\begin{abstract}
Objective: To validate an estimated food record (EFR), using a weighed food record (WFR) as the reference method, for the determination of food consumption and nutrient intakes in a group of Costa Rican adults.

Design: For the WFR, all foods consumed by subjects during seven consecutive days were weighed and recorded by nutrition students. Two EFRs (a 4-day and a 3-day record) were recorded by subjects with the use of home measures and photographs to estimate amounts.

Setting: Costa Rica.

Subjects: Sixty adults: 30 men and 30 women; 30 living in urban and 30 in rural areas. Results: The EFR gave statistically significant lower average intake estimates for energy and 12 of the 22 nutrients examined. The correlation coefficients ranged from 0.68 (polyunsaturated fats) to 0.87 (calcium). The percentage of subjects classified into the same quartile ranged from $45.0 \%$ (polyunsaturated fats) to $68.3 \%$ (vitamin $\mathrm{B}_{12}$ ). For all nutrients except vitamin $\mathrm{C}$, 0 or $1.7 \%$ were misclassified into extreme quartiles. For food group consumption, the EFR gave statistically significant lower estimates for six of the 17 groups and correlation coefficients ranged from 0.22 (fish) to 0.93 (beverages). Greater differences in estimates of mean energy and nutrient intakes were detected among subjects from rural areas, caused in part by a tendency to underestimate the amounts of rice and beans consumed.

Conclusion: Validation of the EFR using a WFR as the reference method gave results that compare favourably with those reported by other authors, and support the use of the EFR for dietary surveys among Costa Rican adults.
\end{abstract}

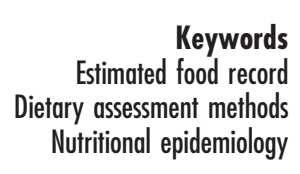

Keywords ary assessment methods Nutritional epidemiology
The health and nutrition situation of the Costa Rican population is one of transition. Health indicators show a reduction in the incidence of childhood infectious diseases and an increase in the prevalence of chronic diseases among adults ${ }^{1}-$ a transformation that is associated with, among other things, changing lifestyle patterns, including changes in diet.

Studies of the diet-health relationship in Costa Rica reported in the literature over the last decade include health problems associated with poverty, such as anaemia and childhood stunting ${ }^{2}$, and studies on the relationship between diet and chronic diseases, such as those on the prevalence of cardiovascular risk factors ${ }^{3,4}$, cervical cancer $^{5-7}$ and gastric cancer ${ }^{8-12}$. The latter is of special interest as Costa Rica has one of the highest incidence and death rates for this type of cancer in the world ${ }^{13}$.

Methods that were used to measure food consumption in these studies include food records, 24-hour recalls and food-frequency questionnaires. The use of food records has an advantage over other methods that measure food consumption retrospectively in that it does not include error due to memory. The food record method was first used in Costa Rica in a National Nutrition Survey in the 1960s, conducted by the Nutrition Institute for Central America and Panama ${ }^{14}$. Two versions of the food record were used, a weighed food record and a daily food record; in both types of records the data collection was carried out by trained fieldworkers. In the case of the weighed food record, the fieldworkers remained in each home throughout the day in order to weigh all food consumed by the family or individual. The daily food record ${ }^{15}$ was devised as a means of reducing costs because it enabled fieldworkers to collect data from two households simultaneously; the fieldworkers visited each house twice a day, between meals, to collect data on the previous and next meal of that family or individual. However, survey costs remain high with this method as it depends on the use of trained fieldworkers to carry out all the data collection.

The work reported in the present paper was undertaken in response to the need to develop and validate other methods which can be used to study the relationship between diet and disease in this country. Methods that estimate food consumption over longer periods of time 
and methods which reduce costs by getting the subjects to register their food consumption are suitable for use in epidemiological studies. The use of food records in which the subjects register their consumption has not been reported in previous literature on Costa Rica. This paper presents the results of a validation of an estimated food record (EFR), carried out by the subjects, using a weighed food record (WFR), collected by undergraduate nutrition students, as the reference method.

\section{Methods}

\section{Data collection}

Data were collected from 60 adults, 15 men and 15 women from a rural community and 15 men and 15 women living in urban areas. The subjects were selected according to the following criteria: (1) Costa Rican; (2) between 20 and 65 years of age; (3) if not literate, lived with someone who was literate; and (4) in the case of rural residents, formed part of families whose income depended in part or totally on agricultural work. In the rural area, subjects were contacted with the help of a primary health worker in the community; in the urban area, the subjects lived within the same neighbourhood as the two nutrition students who collected the WFR data.

All the interviews carried out as part of the EFR were performed by the investigator. The food records for each subject were carried out during a 2-week period, between February 1996 and March 1998. The WFR was performed on days 1 to 7 , the first EFR on days 1 to 4 and the second EFR on days 12 to 14 . As both methods were used simultaneously over four days, this allowed measurement of the degree to which the EFR recorded the same types and amounts of foods as were reported by the WFR.

In the case of the WFR, the nutrition students weighed ingredients of food preparations and food portions as served and plate waste, visiting the house during preparation and consumption of meals. In some cases, where another member of the household was able and willing to assist in the data collection, they were trained to weigh foods consumed by the subject when the nutrition student was not present. Soehnle scales (sensitivity of $1 \mathrm{~g}$ and capacity of $2 \mathrm{~kg}$ ) were used. On all possible occasions, the foods consumed outside the home were weighed prior to consumption. When this was not possible, the students visited the site and weighed a similar portion of the same food. Where it was not possible to weigh the ingredients of preparations consumed away from home, published recipes for the same preparations were used. Subjects were weighed using bathroom scales (sensitivity of $0.5 \mathrm{~kg}$ ) on days 1 and 8. Their height was measured on day 1 .

In order to collect data by the EFR, the investigator visited the subject during the morning of day 2 , to instruct the person on how to complete the 4-day EFR. Food consumption for day 1 was registered in the booklet using a 24 hour-recall, which served the additional purpose of demonstrating to the subject how to record the data. The subject was revisited on day 5 in order to revise, complete any missing information and collect the EFR. The same process was repeated on days 11 and 15, except that on day 11 the EFR booklet was given to the subject with the instruction to record consumption on days 12, 13 and 14. The EFR booklet contained the following sections: (1) instructions on how to record consumption of different foods; (2) pages on which the subject records food consumption for each day, divided into seven mealtime periods; (3) a series of questions at the end of each day to record foods that are commonly eaten between mealtimes and had not been recorded; and (4) aids for the description of portion size, such as drawings of flat, rounded and heaped spoons, diagrams of different sizes and thickness of slices, a centimetre scale and pages containing photographs of between three and six portion sizes for 25 different foods. Each booklet permits the recording of 4 days' food consumption. The portion sizes used for the food photographs were determined in a previous study ${ }^{16}$.

\section{Data analysis}

All 60 subjects completed a total of 7 days of WFR and 7 days of EFR (combination of the 4-day and 3-day records). The estimated amounts of foods consumed according to the EFR were converted to gram weights by the investigator using local tables of food portion sizes ${ }^{17}$ and the weights of foods displayed in photos ${ }^{18}$. The addition of codes for each food for the EFR was performed by the investigator and, in the case of the WFR, by nutrition students previously trained by the investigator. All food consumption data (EFR and WFR) were converted to nutrient values using Central American food composition tables $^{19,20}$ and software created in Epi Info ${ }^{21}$. The average daily nutrient intakes for the WFR and EFR were calculated. Statistical analysis was performed using SPSS version 12.0 for Windows (SPSS Inc., Chicago, IL, USA, 2003). All nutrients with a non-normal distribution were converted to natural logarithms with the exception of vitamin A, which remained non-normal after conversion; the conversion used for this nutrient was $1 / \sqrt{ } \mathrm{x}$. The converted nutrient estimates were compared using the paired Student $t$-test and the degree of association was measured by the Pearson's correlation coefficient. The within- and between-person variance was calculated for both types of record using repeated-measures analysis of variance. The coefficients of variation were calculated by expressing the standard deviation as a percentage of the mean. The intraclass correlation coefficients were calculated using the original, non-transformed nutrient intake values for WFR and EFR. Linear regression analysis was 
performed for the difference* between WFR and EFR energy and nutrient estimates (WFR-EFR) as the dependent variable and sex, area of residence, age and body mass index (BMI) as independent variables. The mean consumption of food groups was compared by Wilcoxon's signed rank test and the degree of association by Spearman's correlation coefficient. The ability of both methods to similarly classify individuals into quartiles of the distributions was also examined.

\section{Results}

\section{Study group characteristics}

The characteristics of the group of subjects are presented in Table 1. There was no difference in average age and educational level of men and women. Significant differences were observed between rural and urban residents: rural residents had spent fewer years in formal education, a higher proportion of them were unskilled rather than skilled workers, and a larger percentage had a monthly income below \$US 250. No association was found between being overweight (BMI $>25 \mathrm{~kg} \mathrm{~m}^{-2}$ ) and sex or between being overweight and area of residence (chi-square test).

\section{Comparison of mean daily energy and nutrient intakes}

Table 2 presents a comparison of the mean intakes of energy and 21 nutrients analysed for the 60 subjects using the 7-day WFR and the 7-day EFR. In the case of energy and 12 nutrients, the EFR estimates were significantly lower than those of the WFR.

The results of linear regression analysis for the effects of the independent variables sex, age, area of residence and BMI on differences between the WFR and EFR estimates for energy and nutrients showed a significant effect only in the case of area of residence for seven nutrients. Another linear regression analysis was performed, with the difference in WFR and EFR nutrient estimates as the dependent variable and area of residence as the independent variable. The results of this analysis are presented in Table 3, where it can be seen that area of residence had a significant effect on the size of the difference between WFR and EFR estimates for energy and 11 nutrients; the difference being greater in rural residents. For example, the degree of underestimation of energy intake by the EFR was $312 \mathrm{kcal}$ greater among rural residents compared with urban residents.

*The distribution of differences between the WFR and EFR nutrient estimates was not significantly different from the normal distribution except for the differences corresponding to vitamins $\mathrm{A}_{\text {and }} \mathrm{B}_{12}$. In the case of these two vitamins, the differences were converted to positive numbers by adding a constant amount to all values and then converted to their natural logarithms.
Table 1 Characteristics of the study group

\begin{tabular}{lccc}
\hline Characteristic & Total & Urban & Rural \\
\hline Age (years), range; & $22-61 ;$ & & \\
$\quad$ mean (SD) & $44.3(11.6)$ & & \\
Number of years spent & $8.7(4.1)$ & $11.2(3.9)$ & $6.2(2.6) \dagger$ \\
$\quad$ in formal education, & & & \\
$\quad$ mean (SD) & & 13.3 & $66.7 \ddagger$ \\
Monthly income below & 38.6 & & \\
$\quad$ \$US 250 (\%) & & & \\
Distribution according to & & 16.7 & $56.7 \S$ \\
occupation (\%) & & 13.3 & 36.7 \\
$\quad$ Unskilled workers & 36.7 & 30.0 & 6.7 \\
$\quad$ Housewives & 25.0 & & \\
$\quad$ Skilled, technical or & 18.3 & 36.7 & 0 \\
$\quad$ professional workers & & 3.3 & 0 \\
$\quad \begin{array}{l}\text { Pensioners } \\
\quad \text { Full-time university }\end{array} \quad 18.3$ & 1.7 & & \\
$\quad$ student & & & \\
Overweight and obesity (\%) & 50.8 & & \\
\hline
\end{tabular}

SD-standard deviation.

†Significant difference between urban and rural residents (Student's $t$-test): $P<0.001$.

$\ddagger$ Significant difference between urban and rural residents (chi-square test): $P<0.001$.

§Significant difference in the proportion of skilled and unskilled workers in urban and rural areas (chi-square test): $P<0.01$.

Table 4 presents the ratio of within- to between-person coefficients of variation for energy and nutrients, for the WFR and the EFR. The nutrients that presented ratios above 1 were vitamins, fats and dietary fibre. Pearson's correlation coefficients for energy and nutrients as estimated by the two methods ranged from 0.68 for polyunsaturated fats to 0.87 for calcium. The intraclass correlation coefficients were lower than the Pearson correlation coefficients in the case of 10 nutrients, and ranged from 0.56 for polyunsaturated fats to 0.90 for calcium.

Table 5 presents the number (and percentage) of subjects who were classified into the same quartile of the distribution according to the energy and nutrient intake estimates from the WFR and the EFR. The values ranged from $45.0 \%$ for polyunsaturated fats to $68.3 \%$ for vitamin $\mathrm{B}_{12}$. For most of the nutrients, 0 or $1.7 \%$ were misclassified into extreme quartiles of the distribution, except in the case of vitamin $\mathrm{C}$ where $3.3 \%$ were misclassified.

Comparison of mean daily food group consumption Table 6 compares the mean consumption of different food groups* as estimated by the WFR and the EFR. In the case of six food groups (chicken, processed meats, legumes, cereals, bread, sugars), the EFR estimates were significantly lower than those of the WFR. The largest mean differences were found for the cereals and legumes food groups. The Spearman correlation coefficients were significant for 16 of the 17 groups.

*Three food groups (pork meat, nuts \& seeds, snacks) were not included due to a large number of zero values. 
Table 2 Comparison of mean energy and nutrient intakes estimated by the weighed food record (WFR) and the estimated food record (EFR)

\begin{tabular}{|c|c|c|c|c|c|c|}
\hline \multirow[b]{2}{*}{ Nutrient } & \multicolumn{2}{|c|}{ WFR } & \multicolumn{2}{|c|}{ EFR } & \multicolumn{2}{|c|}{$\begin{array}{c}\text { Difference } \\
\text { (WFR - EFR) }\end{array}$} \\
\hline & Mean & SD & Mean & SD & Mean† & SE \\
\hline Energy (MJ day ${ }^{-1}$ ) & 9.07 & 3.19 & 8.23 & 2.90 & $0.83^{\star \star \star}$ & 0.22 \\
\hline Protein $\left(\mathrm{g} \mathrm{day}^{-1}\right)$ & 72.2 & 27.05 & 65.1 & 24.10 & $7.1^{\star *}$ & 2.12 \\
\hline Carbohydrate ( day $^{-1}$ ) & 324.9 & 123.96 & 292.3 & 111.78 & $32.5^{\star \star \star}$ & 8.47 \\
\hline Total fat $\left(\mathrm{g} \mathrm{day}^{-1}\right)$ & 66.8 & 24.09 & 62.5 & 24.85 & 4.3 & 2.48 \\
\hline Monounsaturated fat ( $\mathrm{g}_{\text {day }}{ }^{-1}$ ) & 24.63 & 11.18 & 22.37 & 9.93 & $2.26^{*}$ & 1.21 \\
\hline Polyunsaturated fat ( $\mathrm{g}$ day $\left.{ }^{-1}\right)^{\prime}$ & 14.27 & 7.61 & 13.11 & 7.10 & 1.16 & 0.89 \\
\hline Saturated fat $\left(\mathrm{g} \mathrm{day}^{-1}\right)$ & 20.54 & 8.20 & 19.19 & 8.45 & $1.35^{*}$ & 0.76 \\
\hline Cholesterol ( $\mathrm{mg} \mathrm{day}^{-1}$ ) & 280 & 167.54 & 262 & 141.22 & 18 & 12.20 \\
\hline Dietary fibre $\left(\mathrm{g} \text { day }^{-1}\right)^{\prime}$ & 17.01 & 6.39 & 15.05 & 5.92 & $1.96^{\star \star}$ & 0.56 \\
\hline Calcium ( $\mathrm{mg} \mathrm{day}^{-1}$ ) & 689 & 349.28 & 673 & 345.34 & 16 & 19.97 \\
\hline Iron $\left(\mathrm{mg} \mathrm{day}^{-1}\right)$ & 19.1 & 7.70 & 17.4 & 7.22 & $1.7^{\star \star}$ & 0.51 \\
\hline Phosphorus (mg day ${ }^{-1}$ ) & 1087 & 403.60 & 1000 & 373.24 & $87^{\star \star}$ & 29.48 \\
\hline Potassium (mg day ${ }^{-1}$ ) & 2429 & 738.39 & 2347 & 748.19 & 82 & 65.54 \\
\hline Magnesium (mg day ${ }^{-1}$ ) & 235 & 76.84 & 217 & 74.18 & $18^{\star *}$ & 6.21 \\
\hline $\operatorname{Zinc}\left(\mathrm{mg} \mathrm{day}^{-1}\right)$ & 8.94 & 3.65 & 8.02 & 3.28 & $0.91^{\star \star *}$ & 0.27 \\
\hline Retinol equivalents $\left(\mu \mathrm{g}_{\text {day }}{ }^{-1}\right) \ddagger$ & 1018 & 1178.54 & 903 & 854.49 & 114 & 71.26 \\
\hline Thiamin $\left(\mathrm{mg} \mathrm{day}^{-1}\right.$ ) & 1.54 & 0.63 & 1.40 & 0.58 & $0.14^{* *}$ & 0.04 \\
\hline Riboflavin (mg day ${ }^{-1}$ ) & 1.51 & 0.67 & 1.45 & 0.66 & 0.05 & 0.04 \\
\hline Vitamin $\mathrm{B}_{6}\left(\mathrm{mg}\right.$ day $\left.^{-1}\right)$ & 1.42 & 0.46 & 1.32 & 0.54 & $0.10^{\star \star}$ & 0.04 \\
\hline Vitamin $B_{12}\left(\mu \mathrm{g} \mathrm{day}^{-1}\right)$ & 5.54 & 9.62 & 5.06 & 7.59 & 0.48 & 0.52 \\
\hline Vitamin C (mg day $\left.{ }^{-1}\right)$ & 127 & 80.91 & 143 & 96.34 & -17 & 6.86 \\
\hline Folate $\left(\mu \mathrm{g}_{\text {day }}{ }^{-1}\right)$ & 340 & 147.81 & 300 & 117.03 & $40^{\star *}$ & 12.78 \\
\hline
\end{tabular}

SD - standard deviation; SE - standard error.

Significant difference (Student's $t$-test): ${ }^{\star}, P<0.05 ;{ }^{\star \star}, P<0.01 ;{ }^{\star \star \star}, P<0.001$.

† Values for energy and all nutrients, except retinol equivalents, converted to natural logarithms before performing Student's $t$-test.

$\ddagger$ Values converted to $1 / \sqrt{ } \mathrm{x}$ before performing Student's $t$-test.

Table 7 presents the number (and percentage) of subjects classified into the same quartile of the distributions for food group consumption, according to the WFR and the EFR. The values ranged from $36.7 \%$ for soups to $71.7 \%$ for milk \& milk products. For most of the food groups, $5 \%$ or less were misclassified into extreme quartiles of the distribution, except in the case of fish where $6.7 \%$ were misclassified.

\section{Comparison of estimates of energy intake to basal metabolic rate}

When the mean daily energy intake of each individual was compared with the value calculated from the equation

Table 3 Regression analysis of the difference between energy and nutrient intakes estimated by the weighed food record (WFR) and the estimated food record (EFR) (WFR - EFR, dependent variable) and area of residence (independent variable)

\begin{tabular}{lrc}
\hline WFR - EFR for: & $\begin{array}{c}\text { Regression } \\
\text { coefficient }\end{array}$ & Level of significance \\
\hline Energy & 312.18 & 0.003 \\
Protein & 12.32 & 0.003 \\
Total fat & 16.76 & 0.000 \\
Monounsaturated fat & 7.41 & 0.002 \\
Polyunsaturated fat & 3.98 & 0.025 \\
Saturated fat & 4.43 & 0.003 \\
Cholesterol & 51.13 & 0.035 \\
Iron & 2.17 & 0.031 \\
Phosphorus & 151.13 & 0.007 \\
Magnesium & 26.58 & 0.031 \\
Zinc & 1.10 & 0.043 \\
Folate & 61.37 & 0.015 \\
\hline
\end{tabular}

energy intake $=$ basal metabolic rate $\times 1.2$, 16 subjects underreported consumption in the WFR, of whom 10 lost weight during the week when the WFR data were collected. When the same procedure was carried out for the EFR data, 22 subjects were identified as underreporters, of whom nine lost weight during the week when the 7 days of WFR data and the first four days of the EFR data were collected. No association was found between the variable underreporting (in the WFR or the EFR) and overweight, sex or area of residence. However, those individuals who underreported with the WFR were also more likely to underreport with the EFR (chi-square test, $P<0.001$ ).

\section{Factors contributing to differences in mean estimates of energy and nutrient intakes}

The EFR can include two types of error: it can omit foods consumed/include foods not consumed or it can register a different amount of the food consumed. To determine how much these two types of error occurred in the EFR, the data corresponding to the three days* on which both the WFR and the EFR were performed were analysed as follows:

- A comparison was made of the frequency of consumption of different foods and food groups according to the EFR and the WFR.

*The first day of the EFR was not included because the information on foods consumed on that day was collected by a 24-hour recall. 
Table 4 Pearson's and intraclass correlation coefficients for energy and nutrient intakes as estimated by the weighed food record (WFR) and the estimated food record (EFR)

\begin{tabular}{|c|c|c|c|c|}
\hline \multirow[b]{2}{*}{ Nutrient } & \multicolumn{2}{|c|}{$\begin{array}{l}\text { Ratio of } \\
\text { within- to } \\
\text { between- } \\
\text { person } \\
\text { variation }\end{array}$} & \multirow{2}{*}{$\begin{array}{l}\text { Pearson's } \\
\text { correlation } \\
\text { coefficient† }\end{array}$} & \multirow{2}{*}{$\begin{array}{l}\text { Intraclass } \\
\text { correlation } \\
\text { coefficient }\end{array}$} \\
\hline & WFR & EFR & & \\
\hline Energy (MJ day ${ }^{-1}$ ) & 0.64 & 0.66 & $0.85^{\star \star \star}$ & $0.84^{\star \star \star}$ \\
\hline Protein $\left(\mathrm{g}\right.$ day $\left.^{-1}\right)$ & 0.77 & 0.80 & $0.80^{\star \star \star}$ & $0.80^{\star \star \star}$ \\
\hline Carbohydrate $\left(\mathrm{g}\right.$ day $\left.{ }^{-1}\right)$ & 0.62 & 0.68 & $0.86^{\star \star \star}$ & $0.85^{\star \star \star}$ \\
\hline Total fat $\left(\mathrm{g} \mathrm{day}^{-1}\right)$ & 1.04 & 0.87 & $0.73^{\star * *}$ & $0.69^{\star * *}$ \\
\hline $\begin{array}{l}\text { Monounsaturated } \\
\text { fat }\left(\mathrm{g} \mathrm{day}^{-1}\right)\end{array}$ & 1.06 & 0.91 & $0.72^{\star \star \star}$ & $0.61^{\star \star \star}$ \\
\hline $\begin{array}{l}\text { Polyunsaturated } \\
\text { fat }\left(\mathrm{g} \mathrm{day}^{-1}\right)\end{array}$ & 1.71 & 1.20 & $0.68^{\star \star \star}$ & $0.56^{\star \star \star}$ \\
\hline Saturated fat $\left(\mathrm{g}\right.$ day $\left.^{-1}\right)$ & 1.08 & 0.96 & $0.77^{\star \star \star}$ & $0.75^{\star \star \star}$ \\
\hline Cholesterol $\left(\mathrm{mg} \mathrm{day}^{-1}\right)$ & 1.07 & 1.15 & $0.84^{\star \star \star}$ & $0.81^{\star \star \star}$ \\
\hline Dietary fibre $\left(\mathrm{g} \mathrm{day}^{-1}\right)^{\prime}$ & 1.08 & 1.02 & $0.80^{\star \star \star}$ & $0.75^{\star \star \star}$ \\
\hline Calcium (mg day ${ }^{-1}$ ) & 0.81 & 0.74 & $0.87^{\star \star \star}$ & $0.90^{\star \star *}$ \\
\hline Iron $\left(\mathrm{mg}\right.$ day $\left.^{-1}\right)$ & 0.93 & 0.90 & $0.85^{\star \star \star}$ & $0.86^{\star \star *}$ \\
\hline Phosphorus (mg day ${ }^{-1}$ ) & 0.72 & 0.71 & $0.84^{\star \star \star}$ & $0.84^{\star \star \star}$ \\
\hline Potassium (mg day $\left.{ }^{-1}\right)^{\prime}$ & 0.92 & 0.91 & $0.76^{\star \star \star}$ & $0.77^{\star \star \star}$ \\
\hline Magnesium $\left(\mathrm{mg} \mathrm{day}^{-1}\right)$ & 0.83 & 0.83 & $0.80^{\star \star \star}$ & $0.80^{\star \star \star}$ \\
\hline Zinc $\left(\mathrm{mg} \mathrm{day}^{-1}\right)$ & 0.94 & 1.07 & $0.83^{\star \star \star}$ & $0.82^{\star \star \star}$ \\
\hline $\begin{array}{l}\text { Retinol equivalents } \\
\qquad\left(\mu \mathrm{g} \text { day }^{-1}\right) \ddagger\end{array}$ & 1.40 & 2.02 & $0.75^{\star \star \star}$ & $0.86^{\star \star \star}$ \\
\hline Thiamin $\left(\mathrm{mg}\right.$ day $\left.^{-1}\right)$ & 0.76 & 0.84 & $0.82^{* \star *}$ & $0.85^{\star \star \star}$ \\
\hline Riboflavin (mg day ${ }^{-1}$ ) & 1.17 & 1.19 & $0.84^{\star \star \star}$ & $0.86^{\star \star \star}$ \\
\hline Vitamin $B_{6}\left(m g\right.$ day $\left.{ }^{-1}\right)$ & 1.19 & 0.99 & $0.76^{\star \star \star}$ & $0.77^{\star \star \star}$ \\
\hline Vitamin $B_{12}\left(\mu \mathrm{g} \mathrm{day}^{-1}\right)$ & 1.61 & 2.22 & $0.84^{\star \star \star}$ & $0.89^{\star \star *}$ \\
\hline Vitamin C (mg day $\left.{ }^{-1}\right)$ & 1.30 & 1.12 & $0.74^{* \star *}$ & $0.82^{* * *}$ \\
\hline Folate $\left(\mu \mathrm{g}\right.$ day $\left.^{-1}\right)$ & 0.90 & 0.97 & $0.79^{\star \star \star}$ & $0.72^{\star \star \star}$ \\
\hline
\end{tabular}

Significant correlation: ${ }^{* * *}, P<0.001$

†Values for energy and all nutrients, except retinol equivalents, converted to natural logarithms before calculating correlation coefficient.

$\ddagger$ Values converted to $1 / \sqrt{ } \mathrm{x}$ before calculating correlation coefficient.

Table 5 Classification of subjects in quartiles of energy and nutrient intakes as estimated by the weighed food record and the estimated food record

\begin{tabular}{lcc}
\hline Nutrient & $\begin{array}{c}\text { No. (\%) classified } \\
\text { into the same quartile }\end{array}$ & $\begin{array}{c}\text { No. (\%) misclassified } \\
\text { into extreme } \\
\text { quartiles }\end{array}$ \\
\hline Energy & $36(60.0)$ & $1(1.7)$ \\
Protein & $38(63.3)$ & $1(1.7)$ \\
Carbohydrate & $33(55.0)$ & 0 \\
Total fat & $31(51.7)$ & $1(1.7)$ \\
Monounsaturated fats & $30(50.0)$ & 0 \\
Polyunsaturated fats & $27(45.0)$ & $1(1.7)$ \\
Saturated fat & $31(51.7)$ & $1(1.7)$ \\
Cholesterol & $32(53.3)$ & 0 \\
Dietary fibre & $35(58.3)$ & 0 \\
Calcium & $32(53.3)$ & 0 \\
Iron & $33(55.0)$ & 0 \\
Phosphorus & $37(61.7)$ & $1(1.7)$ \\
Potassium & $33(55.0)$ & $1(1.7)$ \\
Magnesium & $37(61.7)$ & $1(1.7)$ \\
Zinc & $35(58.3)$ & 0 \\
Retinol equivalents & $34(56.7)$ & $1(1.7)$ \\
Thiamin & $32(53.3)$ & $1(1.7)$ \\
Riboflavin & $39(65.0)$ & 0 \\
Vitamin $B_{6}$ & $34(56.7)$ & $1(1.7)$ \\
Vitamin $B_{12}$ & $41(68.3)$ & $1(1.7)$ \\
Vitamin C & $28(46.7)$ & $2(3.3)$ \\
Folate & $33(55.0)$ & $1(1.7)$ \\
\hline
\end{tabular}

Table 6 Food group consumption $\left(\mathrm{g} \mathrm{day}^{-1}\right.$ ) as estimated by the weighed food record (WFR) and the estimated food record (EFR)

\begin{tabular}{|c|c|c|c|}
\hline \multirow[b]{2}{*}{ Food group } & \multicolumn{2}{|c|}{ Mean (SD) } & \multirow{2}{*}{$\begin{array}{l}\text { Spearman's } \\
\text { correlation } \\
\text { coefficient }\end{array}$} \\
\hline & WFR & EFR $\ddagger$ & \\
\hline Milk \& milk products & 215.9 (170.7) & $231.6(192.8)$ & $0.85^{\star \star \star}$ \\
\hline Eggs & $27.0(26.4)$ & $27.4(23.9)$ & $0.72^{\star \star \star}$ \\
\hline Chicken (raw) & 37.5 (33.1) & $28.4(29.4)^{\star \star}$ & $0.57^{\star \star}$ \\
\hline Beef (raw) & $61.2(48.5)$ & 60.7 (49.9) & $0.73^{\star \star \star}$ \\
\hline Processed meats & $13.5(14.9)$ & $10.4(10.2)^{\star \star}$ & $0.65^{\star \star \star}$ \\
\hline Fish (raw) & $18.2(20.3)$ & $19.0(20.8)$ & 0.22 \\
\hline Legumes (raw) & $33.5(29.2)$ & $22.0(18.0)^{\star \star \star}$ & $0.79^{\star * *}$ \\
\hline Beverages & 519.7 (379.8) & $517.2(354.2)$ & $0.93^{\star \star \star}$ \\
\hline Soups & $42.7(46.9)$ & $47.3(53.9)$ & $0.53^{\star \star *}$ \\
\hline Starchy vegetables & $57.3(38.6)$ & $61.6(44.4)$ & $0.60^{\star \star \star}$ \\
\hline Other vegetables & $166.1(84.6)$ & $179.1(98.5)$ & $0.72^{\star \star *}$ \\
\hline Cereals (raw) & $128.2(66.1)$ & $105.2(62.2)^{\star \star \star}$ & $0.79^{\star \star *}$ \\
\hline Bread & 113.1 (73.4) & $100.0(57.6)^{\star}$ & $0.77^{\star \star *}$ \\
\hline Fruit & $159.6(140.4)$ & 166.7 (156.9) & $0.75^{\star \star \star}$ \\
\hline Sugars & $72.6(51.3)$ & $65.7(54.0)^{\star}$ & $0.81^{* * *}$ \\
\hline Fat & $29.7(18.5)$ & $26.2(19.5)$ & $0.42^{\star \star}$ \\
\hline Cakes & $18.7(22.2)$ & $22.2(26.8)$ & $0.55^{\star \star \star}$ \\
\hline
\end{tabular}

SD - standard deviation.

Significant difference or correlation: ${ }^{*}, P<0.05 ;{ }^{* *}, P<0.01 ;{ }^{* \star *}, P<0.001$. †Three food groups (nuts \& seeds, pork meat, snacks) were excluded due to a large number of zero values.

$\ddagger$ Wilcoxon's signed rank test.

- The difference in quantity of each food recorded by the EFR and the WFR was calculated.

The exact same foods were reported by both methods at the same mealtime on $70.8 \%$ of occasions ( 5735 of a total of 8105 records). Some 1137 additional foods (an average of 2.7 foods per person per day) were recorded for the EFR but not for the WFR, and 1233 (an average of 2.9 foods per person per day) were reported in the WFR but not in the

Table 7 Classification of subjects in quartiles of food group consumption $\dagger$ as estimated by the weighed food record and the estimated food record

\begin{tabular}{lcc}
\hline Food group & $\begin{array}{c}\text { No. (\%) classified } \\
\text { into the same quartile }\end{array}$ & $\begin{array}{c}\text { No. (\%) misclassified } \\
\text { into extreme } \\
\text { quartiles }\end{array}$ \\
\hline Milk \& milk products & $43(71.7)$ & 0 \\
Eggs & $32(53.3)$ & 0 \\
Chicken (raw) & $31(51.7)$ & $1(1.7)$ \\
Beef (raw) & $29(48.3)$ & $1(1.7)$ \\
Processed meats & $33(55.0)$ & $3(5.0)$ \\
Fish (raw) & $27(45.0)$ & $4(6.7)$ \\
Legumes (raw) & $37(61.7)$ & 0 \\
Beverages & $40(67.7)$ & 0 \\
Soups & $22(36.7)$ & $2(3.3)$ \\
Starchy vegetables & $28(46.7)$ & $3(5.0)$ \\
Other vegetables & $35(58.3)$ & 0 \\
Cereals (raw) & $34(56.7)$ & $1(1.7)$ \\
Bread & $34(56.7)$ & 0 \\
Fruit & $32(53.3)$ & $1(1.7)$ \\
Sugars & $31(51.7)$ & 0 \\
Fat & $26(43.3)$ & $2(3.3)$ \\
Cakes & $30(50.0)$ & $2(3.3)$ \\
\hline
\end{tabular}

†Three food groups (nuts \& seeds, pork meat, snacks) were excluded due to a large number of zero values. 
EFR. In the case of nine food groups, the EFR tended to overestimate the number of times foods were consumed; for seven food groups it tended to underestimate the number of times foods were consumed; and for two food groups there was no tendency in either direction. From this finding, it can be said that no marked tendency was observed among the food groups to either under- or overestimate the number of times foods were recorded.

When the differences in quantity of each food as estimated by the EFR and the WFR were observed, there was a tendency of the EFR to underestimate amount consumed. For all foods, the EFR underestimated amount on $51.1 \%$ of occasions and overestimated amount on $42.9 \%$ of occasions. The same tendency was observed for 13 of the 18 food groups, and was more pronounced for the following food groups: processed meats, legumes, cereals, sugars and fats. Portion size of processed meats was estimated in the EFR by dimensions or number of units; sugars and fats as number of spoonfuls. The most important foods in terms of amounts eaten in the cereal and legume groups are rice and beans, respectively. The portion sizes of these foods were estimated by photographs of six portions in each case. The use of an inappropriate range of portion sizes in the photos could have caused an underestimation of amount consumed in the EFR. However, this was not the case. According to the WFR, 98.1\% of values for rice consumption and $91.8 \%$ of values for bean consumption at one meal were below the maximum portion sizes displayed in the photos of these foods.

\section{Discussion}

The results of this study compare favourably with those of similar studies reported in the literature. In the studies of Bransby et $a l .^{22}$, Edington et al. ${ }^{23}$, Todd et al. ${ }^{24}$, Bingham et $a l^{25}$ and Bonifacj et al. ${ }^{26}$, an EFR was compared with a WFR. Karvetti and Knuts ${ }^{27}$ and Crawford et al. ${ }^{28}$ compared an EFR with observed intake and Nettleton et $a l^{29}$ compared an EFR with a semi-weighed food record.

The comparison of mean estimates of energy and nutrient intake between the two methods gave similar results to those reported by Nettleton et al. ${ }^{29}$ and Karvetti and Knuts ${ }^{27}$, where approximately half of the nutrients showed statistically significant differences. In other studies ${ }^{23-25,28}$ fewer differences were found and in one study ${ }^{26}$ most nutrients were significantly different. The associations between the energy and nutrient intake estimates were higher on average in this study than those reported by Bingham et al. ${ }^{25}$, Edington et $a l^{23}$ and Bonifacj et $a l^{26}$, but lower than those reported by Bransby et $a l^{22}$, Karvetti and Knuts ${ }^{27}$ and Crawford et $a l^{28}$. The only other studies presenting the distribution in quartiles of energy and nutrient intakes were those of Bingham et ll. $^{25}$ and Bonifacj et $a l^{26}$. The present data compare favourably with those presented in these studies: the percentage of subjects correctly classified was $45-68 \%$ in this study, 37-70\% in that of Bingham et $a .^{25}$ and $33-68 \%$ in that of Bonifacj et $a l^{26}$.

Bingham et al..$^{25}$ and Bonifacj et al. ${ }^{26}$ also reported within- and between-person variation for the WFR, and in addition Bonifacj et al. ${ }^{26}$ gave this information for the EFR. The present study found lower ratios of within- to between-person variation than reported by these other authors. Half of the ratios of within- to between-person variation for the WFR were less than 1 in the present study, whereas this ratio was above 1 for the majority of nutrients in the studies of Bingham et $a l^{25}$ and Bonifacj et $a l^{26}$. A comparison of the individual coefficients of variation between the different studies showed that this difference was due to a much larger between-person variation in the present study. This is probably due to the fact that Bingham et al.'s study group was composed exclusively of women between 50 and 65 years of age $\mathrm{e}^{25}$. More variation existed in Bonifacj et al.'s study ${ }^{26}$ : the group consisted of 87 men and women from rural and urban areas. However, it would seem that food habits varied to a lesser extent between individuals than in the present study.

The first four days of the EFR coincided with the first four days of the WFR. While this design was chosen to permit a comparison of food consumption as estimated by both methods over the same period of time, it is possible that contamination occurred between the two methods. During data collection, every effort was made to ensure that the individual was not involved in the weighing and recording for the WFR; however, the presence of a fieldworker in the house during this period would obviously focus more attention on food consumption. When a comparison of the log-transformed average nutrient intakes as estimated by the EFR and the WFR for the same 3-day* period was made (Student's paired $t$-test), the results were similar to those of the comparison between the two 7-day periods: i.e. 13 nutrients presented statistically significant differences $(P<0.05)$. The degree of correlation (Pearson's correlation coefficient) between the log-transformed average nutrient intakes from the EFR and the WFR over the 3-day period was lower than those corresponding to the 7-day periods.

The WFR was different from the EFR in that it was performed over seven consecutive days, whereas the latter consisted of two periods of 4 days and 3 days of records. The two separate periods for the EFR was considered necessary in order to reduce the risk of losing data from subjects who might not have collaborated with recording food consumption over seven consecutive days. This was not considered a problem with the WFR as the data collection was carried out by fieldworkers.

*The first day of the EFR was not included because the information on foods consumed on that day was collected by a 24-hour recall. 
Area of residence was a major contributor to differences in the mean estimates between the two methods. Rural residents presented greater differences between the EFR and WFR nutrient estimates, especially in the estimation of portion sizes of rice and beans. These are the basic staple foods in the Costa Rican diet, together providing 30.6\% of total energy consumption per capita with a higher consumption in rural areas ${ }^{30}$. In the present study, these two foods contributed together an average of $19.1 \%$ of total energy intake (22.7\% in rural areas and $14.6 \%$ among urban inhabitants). A possible reason for the underestimation of these foods in rural areas is that people are unwilling to report consuming large portion sizes, because the consumption of large amounts of these foods in combination with a low consumption of animal products could be associated with a lower socio-economic status.

The principal advantage of the EFR is that it is more accurate than methods that measure past intake ${ }^{31}$ and, although it incurs greater error than the WFR due to estimation of amounts of foods consumed, the present study shows that the EFR is able to estimate mean energy and nutrient intakes to within $10 \%$ of the WFR values, except for vitamin C. The EFR also offers advantages in terms of fieldworker costs. In order to collect three or four days of food consumption data, the EFR requires two interviews by a fieldworker. Two 24-hour recalls would require the same fieldworker time and only collect two days of food consumption data. In Costa Rica it is not feasible for individuals to weigh their own food consumption, due to the costs of the equipment and the high degree of subject collaboration required, so a WFR has very high fieldworker costs.

One of the limitations of the EFR is that it requires more cooperation from subjects than methods which are limited to a single interview. This could produce a lower response rate. However, the degree to which individuals are motivated to participate can increase the response rate. In this study, each subject received individual dietary assessment and recommendations, and this was considered by many subjects as the factor that most motivated them to take part in the study. Even illiteracy was not an obstacle to participating and, in the few cases where the subject was illiterate, another member of the family agreed to complete their EFR for them. Another potential source of error is that subjects tend to change eating habits when keeping food records ${ }^{31}$, particularly reducing food consumption. This has been identified as underreporting $^{32-34}$. It was also detected in the present study and occurred in both types of food record. Although subjects were instructed to eat as normal throughout the study period, a considerable number actually lost weight during the week in which the WFR was performed. The possible reason for this is that when attention is paid to food intake, people unconsciously or consciously tend to consume less, perhaps in order to lose weight or to avoid having to record foods. It has been commented among nutritionists in Costa Rica that getting patients to keep food records helps them keep to weight-reducing diets. A partial solution to this problem would be to detect and exclude the records from those individuals who are identified as underreporters or who lose weight over the recording period. Finally, one way of reducing data processing costs and possible errors in coding of foods, and of making the task of keeping an EFR easier for individuals, is to develop a 'checklist' type of food record ${ }^{25}$.

\section{Conclusions}

Validation of an EFR using a WFR as the reference method gave results that compare favourably with those reported by other authors, and support the use of the EFR for dietary surveys among Costa Rican adults. Greater differences in estimates of mean energy and nutrient intake were detected among subjects from rural areas, caused in part by a tendency to underestimate the amounts of rice and beans consumed. The use of additional aids is recommended in estimating portion sizes of these two foods for subjects from rural areas.

\section{Acknowledgements}

This research was made possible by the financial support provided by the Vice Rectory for Investigation of the University of Costa Rica, with additional funding by the Latin American office of UNESCO. I am grateful for the assistance provided by Dr Michael Nelson of the Department of Nutrition and Dietetics at Kings' College London, during the design and data collection stages of this project and by Dr Xinia Fernández, Dr Sandra Murillo, Dr Doris Soza, Miriam León and Ericka Méndez during the data analysis stage. My gratitude extends to the nutrition students Sylvia Chanto, Eliana Vasco, Ana Gómez and Vielka Betancourt and to all those whose willingness to provide information about their food consumption made this study possible.

\section{References}

1 Organización Panamericana de la Salud (OPS)/Organización Mundial de la Salud (OMS). La Salud en las Américas, Vol. II. Scientific Publication No. 569. Washington, DC: OPS/OMS, 1998.

2 Broitman Tropper, I, Elizondo Salas, M, León León, H, León Orozco S. Patrón alimentaria, densidad energética y de nutrientes de la dieta de niños menores de tres años con retardo en el crecimiento y/o con anemia ferropénica. Thesis presented for Licentiate degree, University of Costa Rica, San José, 1996 [unpublished].

3 Campos H, Mata L, Siles X, Vives M, Ordovas J, Schaefer EJ. Prevalence of cardiovascular risk factors in rural and urban Costa Rica. Circulation 1992; 85: 648-58.

4 Kabagambe EK, Baylin A, Siles X, Campos H. Individual saturated fatty acids and nonfatal acute myocardial infarction 
in Costa Rica. European Journal of Clinical Nutrition 2003; 57: $1447-57$.

5 Herrero R, Potischman N, Brinton LA, Reeves WC, Brenes MM, Tenorio F, et al. A case-control study of nutrient status and invasive cervical cancer 1. Dietary indicators. American Journal of Epidemiology 1991; 134: 1335-46.

6 Potischman N, Herrero R, Brinton LA, Reeves WC, Stacewicz-Sapuntzakis M, Jones CJ, et al. A case-control study of nutrient status and invasive cervical cancer. II. Serologic indicators. American Journal of Epidemiology 1991; 134: 1347-55.

7 Potischman N, Brinton LA, Laiming VA, Reeves WC, Brenes MM, Herrero R, et al. A case-control study of serum folate levels and invasive cervical cancer. Cancer Research 1991; 51: $4785-9$.

8 Sierra R, Barrantes R. Epidemiología y ecología del cáncer gástrico en Costa Rica. Boletin de la Oficina Sanitaria Panamericana 1983; 95: 495-506.

9 Sierra R, Barrantes R. Aspectos ecológicos del cáncer gástrico en Costa Rica. Revista de Biología Tropical 1983; 31: 11-8.

10 Sierra R, Chinnock A, Ohshima H, Pignatelli B, Malaveille C, Gamboa C, et al. In vivo nitrosoproline formation and other risk factors in Costa Rican children from high- and low-risk areas for gastric cancer. Cancer Epidemiology, Biomarkers $\varepsilon$ Prevention 1993; 2: 563-8.

11 Sierra R, Rosero L, Antich D, Muñoz G. Cáncer en Costa Rica, Epidemiología Descriptiva. San José: Editorial de la Universidad de Costa Rica, 1995.

12 Sierra R, Salas P, Mora-Zúñiga F, Sanabria M, Chinnock A, Peña S, et al. Erradicación de Helicobacter pylori en una población de alto riesgo de cáncer gástrico. Acta Médica Costarricense 1998; 40: 30-5.

13 International Agency for Research on Cancer. GLOBOCAN 2002 homepage: http://www-dep.iarc.fr/. Accessed 10 February 2005.

14 Instituto de Nutrición de centroamérica y Panamá (INCAP)/ Oficina de Investigaciones Internacionales de los Institutos Nacionales de Salud. Evaluación nutritional de la población de Centro América y Panamá. INCAP Vol. 28. INCAP: Guatemala City, 1969.

15 Flores M, Menchú MT, Guzmán MA. Evaluación dietética de familias y preescolares mediante la aplicación de diferentes métodos y técnicas - área rural de Nicaragua. Archivos Latinoamericanos de Nutrición 1973; 23: 325-34.

16 Chinnock A. Tamaño de la porción de algunos alimentos y preparaciones para preescolares y adultos de un área ruraly una comunidad urbana del Valle Central de Costa Rica. San José: Universidad de Costa Rica, 1992.

17 Chaverri MA, Rodríguez AM, Chinnock A. Peso de medidas caseras y porciones de alimentos y preparaciones comunes en Costa Rica. San José: Escuela de Nutrición, Facultad de Medicina, Universidad de Costa Rica, 2001.

18 Chinnock A, Sedó Masis P. Porciones de alimentos $y$ preparaciones comunes en Costa Rica y equivalencias del sistema de listas de intercambio. San José: Oficina de Publicaciones Universidad de Costa Rica, 2001.

19 Menchú MT, Méndez H, Barrera MA, Ortega L. Tabla de composición de alimentos de Centroamérica: primera sección. Guatemala City: Institute of Nutrition of Central America and Panama/Pan American Health Organization, 1996.
20 Menchú MT, Méndez H, Lemus J. Tabla de composición de alimentos de Centroamérica: segunda sección. Guatemala City: Institute of Nutrition of Central America and Panama/Pan American Health Organization, 2000.

21 Dean AG, Arner TG, Sangam S, Sunki G, Friedman R, Lantinga M, et al. Epi Info 2002. Atlanta, GA: Centers for Disease Control and Prevention, 2002.

22 Bransby ER, Daubney CG, King J. Comparison of results obtained by different methods of individual dietary survey. British Journal of Nutrition 1948; 2: 89-110.

23 Edington J, Thorogood M, Geekie M, Ball M, Mann J. Assessment of nutritional intake using dietary records with estimated weights. Journal of Human Nutrition and Dietetics 1989; 2: 407-14.

24 Todd KS, Hudes M, Calloway DH. Food intake measurement: problems and approaches. American Journal of Clinical Nutrition 1983; 37: 139-46.

25 Bingham SA, Gill C, Welch A, Day K, Cassidy A, Khaw KT, et al. Comparison of dietary assessment methods in nutritional epidemiology: weighed records v. $24 \mathrm{~h}$ recalls, food-frequency questionnaires, and estimated-diet records. British Journal of Nutrition 1994; 72: 619-43.

26 Bonifacj C, Gerber M, Scali J, Daures JP. Comparison of dietary assessment methods in a Southern French population: use of weighed records, estimated-diet records and a food-frequency questionnaire. European Journal of Clinical Nutrition 1997; 51: 217-31.

27 Karvetti R, Knuts L. Validity of the estimated food dietary: comparison of 2-day recorded and observed food and nutrient intakes. Journal of the American Dietetic Association 1992; 92: 580-4.

28 Crawford PB, Obarzanek E, Morrison J, Sabry ZI. Comparative advantage of 3-day records over 24-hour recall and 5-day food frequency validated by observation of 9- and 10-year-old girls. Journal of the American Dietetic Association 1994; 94: 626-30.

29 Nettleton PA, Day KC, Nelson M. Dietary survey methods 2: a comparison of nutrient intakes within families assessed by household measures and the semi-weighed method. Journal of Human Nutrition 1980; 34: 349-54.

30 Ministerio de Salud. Encuesta Nacional de Nutrición: Fascículo 3 Consumo Aparente. San José, Costa Rica: Ministerio de Salud, 1996.

31 Bingham SA. The dietary assessment of individuals; methods, accuracy, new techniques and recommendations. Nutrition Abstracts and Reviews (Series A) 1987; 57: 705-42.

32 Seale JL, Rumpler WV. Comparison of energy expenditure measurements by diet records, energy intake balance, doubly labeled water and room calorimetry. European Journal of Clinical Nutrition 1997; 51: 856-63.

33 Black AE, Prentice AM, Goldberg GR, Jebb SA, Bingham SA, Livingstone MBE, et al. Measurements of total energy expenditure provide insights into the validity of dietary measurements of energy intake. Journal of the American Dietetic Association 1993; 93: 572-9.

34 Hill RJ, Davies PSW. The validity of a four day weighed food record for measuring energy intake in female classical ballet dancers. European Journal of Clinical Nutrition 1999; 53 : $752-4$. 